аспірант кафедри кримінального права та процесу Львівського торговельно-економічного університету (м. Львів, Україна)

\title{
ПРОТИДІЯ З БОКУ ЗАЦІКАВЛЕНИХ ОСІБ ТА ЗАСОБИ ЇЇ ПОДОЛАННЯ ПРИ РОЗСЛІДУВАННІ ПЕРЕВИЩЕННЯ ВЛАДИ АБО СЛУЖБОВИХ ПОВНОВАЖЕНЬ СПІВРОБІТНИКАМИ ПРАВООХОРОННИХ ОРГАНІВ
}

У статті розглянуто концептуальні підходи до розуміння протидії розслідуванню з боку зацікавлених осіб; виокремлено форми, види, прийоми, коло суб'єктів, способи та засоби ефективного подолання цих протиправних дій. Запропоновано під протидією розслідуванню розуміти будь-які дії чи бездіяльність, спрямовані на перешкоджання досягненню завдань розслідування, приховання слідів злочинів, вплив на учасників кримінального провадження, створення перешкод при відшуканні криміналістично значущої інформації, формуванні системи доказів. Спираючись на результати емпіричного спостереження, виокремлено найбільш розповсюджені форми протидії розслідуванню 3 боку працівників правоохоронних органів, які перевищили владу або службові повноваження. Наголошено, що поряд 3 традиційними, усталеними суб'єктами, такими, як підозрювані (обвинувачені), їхні співучасники, родичі, близькі, знайомі та захисники, активну участь у протидії розслідуванню беруть корумповані службовці органів влади, суду, прокуратури, національної поліції, пенітенціарної служби, засобів масової інформації. Звернуто увагу на те, що ефективна система заходів подолання протидії розслідуванню має декілька рівнів, де особливого значення набувають рекомендації з необхідності проведення кримінологічної експертизи нормативно правових актів через призму чинного антикорупційного законодавства та активізації діяльності державного бюро розслідування, за умов належного його комплектування відповідними кадрами.

Ключові слова: досудове розслідування перевищення влади або службових повноважень співробітниками правоохоронних органів, протидія 3 боку зацікавлених осіб, форми протидії розслідуванню, суб'єкти протидії розслідуванню, засоби подолання протидії розслідуванню.

Постановка проблеми. Специфічною ознакою досудового розслідування службових злочинів, серед яких і перевищення влади або службових повноважень, слід вважати наявність протидії встановленню об'єктивної істини з боку зацікавлених осіб. Попри те, що протидія розслідуванню набула широкомасштабного характеру, ставши вкрай негативним соціальним явищем, серед науковців не існує єдиної позиції щодо визначення цієї криміналістичної категорії; по-різному класифікуються ऑї форми, види, прийоми, не однозначне й коло иї суб' єктів $[1 ; 2 ; 3 ; 4]$. Зазначене ставить перед ученими-криміналістами завдання щодо дальшого поглибленого дослідження цієї проблематики задля вироблення уніфікованих підходів до розуміння цієї криміналістичної категорії та на підставі цього надання рекомендацій, спрямованих на оптимізацію організації досудового розслідування визначеної категорії кримінальних правопорушень. 
Аналіз останніх досліджень і публікацій. Проблема оптимізації досудового розслідування, зокрема в спосіб надання рекомендацій 3 подолання протидії встановленню об'єктивної істини з боку зацікавлених осіб, завжди перебувала в колі наукових інтересів учених-криміналістів. Цій проблематиці присвятили свої роботи такі вітчизняні та зарубіжні науковці, як О. В. Александренко, Л. І. Аркуша, Е. У. Бабаєва, М. О. Баєв, С. В. Бажанов, Р. С. Бєлкін, А. Ф. Волобуєв, Ю. П. Гармаєв, С. Ф. Денисюк, В. М. Карагодін, В. І. Куліков, В. О. Образцов, М. В. Салтевський, О. Л. Стулин, В. В. Трухачев, І. А. Цховребова, В. Ю. Шепітько, Р.М.Шехавцов, Б. В. Щур, О. В. Юнацький, М. П. Яблоков та інші. Водночас питанню протидії з боку зацікавлених осіб та засобам пї подолання при розслідуванні перевищення влади або службових повноважень співробітниками правоохоронних органів належної уваги у вітчизняній криміналістичній літературі не приділялось.

Формування цілей. Метою статті $є$ аналіз висловлених науковцями підходів до розуміння поняття протидії розслідуванню, визначення найбільш поширених форм протидії при розслідуванні перевищення влади або службових повноважень співробітниками правоохоронних органів, надання рекомендацій з подолання цих форм протидії.

Виклад основного матеріалу. Учені-криміналісти за їхніми поглядами щодо поняття протидії розслідуванню належать до прибічників вузького та широкого розуміння цієї категорії. У вузькому розумінні протидія розслідуванню розглядається лише як протиправні дії учасників кримінального судочинства, тобто тільки ті дії (бездіяльність), за виконання або невиконання яких передбачена правова відповідальність.

У широкому розумінні до протидії розслідуванню належать не лише дії (бездіяльність) суб'єктів (як учасників кримінального провадження, так і інших осіб), що мають навмисний характер - перешкодити розслідуванню злочину, але й дії, пов'язані 3 наданням свідком перекручених відомостей при допиті внаслідок сумлінної омани або неправильної оцінки чиїхось дій, байдужим ставленням до процесу розслідування, а також несумлінним ставленням до своїх службових або процесуальних обов'язків (нехтування процесуальними строками, установленими законодавством), з недбалістю (знищення фахівцем слідів на місці події через недотримання правил роботи з ними), бажанням самоусунутися (коли потенційні свідки «нічого не чули й не бачили» через небажання мати справу зі співробітниками правоохоронних органів).

Щодо цього І. А. Цховребова наголошує, що протидія розслідуванню є суто криміналістичною категорією, яку не можна ототожнювати із правовою матерією. Зміст цього поняття має бути наповненим винятково інформацією криміналістичного, а не кримінально-правого значення. Тому навмисне чи ненавмисне, протиправне чи непротиправне створення будь-яким учасником кримінального судочинства або іншою сторонньою особою перешкод процесу розслідування, пов'язане 3 впливом на інформацію або ії носія, слід розглядати як протидію здійсненню досудового розслідування злочинів у широкому розумінні [5, с. 410]. 
Широке трактування поняття протидії розслідуванню надало підстави його прибічникам виокремити ще два питання цієї проблематики: 1) вплив чинного законодавства, передусім кримінального процесуального, на реалізацію наміру з протидії розслідуванню; 2) роль захисників (професійних адвокатів) у протидії розслідуванню.

Зауважимо, що стосовно зазначених питань науковці й практики висловлювали неоднозначні судження. Зокрема, С. В. Бажанов вважає, що сучасна кримінально-процесуальна політика культивує об'єктивні передумови для легітимної протидії розслідуванню учасниками кримінального процесу, що представляють інтереси сторони захисту [6, с. 56]. У спеціальній літературі висловлена думка, що законодавець надав широке коло правових засобів із захисту прав i інтересів, зокрема підозрюваного, обвинувачуваного, багато в чому навіть не обмежуючи ці можливості, що стало зворотним боком кримінально-процесуального принципу змагальності. У сторони захисту, що керується настановою «дозволено все те, що не заборонено законом», з'явилися законні підстави для діяльності, спрямованої на перешкоджання розслідуванню злочинів. Звідси виникло таке поняття, як «правомірна, законна, легальна протидія розслідуванню», - 3 погляду логіки за формою нібито навіть некоректне. Проте ним послуговуються в науковому обігу; його використовує багато вчених, зазначаючи, що на сьогодні вже не потрібно вдаватися до «брудних» способів протидії розслідуванню (фізичному усуненню свідків і потерпілих, шантажу й погрозам тощо), а досягти мети протидії розслідуванню ухилитися від кримінальної відповідальності за вчинений злочин - цілком реально законними методами [7; 8; 9, с. 18-23; 10; 11, с. 5-9; 12, с. 6-8].

Щодо чинного кримінального процесуального законодавства України, то воно, дійсно, охоплюе окремі положення, які дещо утруднюють процедуру формування доказової бази й доведення винуватості конкретної особи. Йдеться передусім про обмежене коло підстав затримання особи, підозрюваної у вчиненні кримінального правопорушення без ухвали слідчого судді (ст. 207, 208 КПК України), ускладнену процедуру оголошення в розшук підозрювано-го (ст. 281 КПК) або отримання дозволу на провадження окремих слідчих (розшукових) дій, зокрема огляду (ст. 237 КПК) та обшуку (статті 234, 235, 236 КПК) житла чи іншого володіння особи. Скажімо, у Кримінально-процесуальному кодексі України 1960 року (статті 106, 1061, 115 КПК) передбачалося більше підстав, порівняно з чинним, для здійснення законного затримання особи, підозрюваної у вчиненні злочину, особливо в тих випадках, коли вона зникла з місця події, а згодом стало відомо про ії місцезнаходження. Крім того, за чинним КПК оголосити в розшук можна тільки підозрювану особу, тобто особу, якій повідомлено про підозру або яку затримано за підозрою у вчиненні кримінального правопорушення (ст. 42 КПК). Це положення суттєво утруднює або навіть унеможливлює оголошення в розшук особи, яка вчинивши злочинні дії, зникла з місця події, хоча слідство має достеменні відомості про неї (момент учинення протиправних дій зафіксовано на камерах відеоспостереження й особу впізнано, на неї вказують декілька свідків - очевидців тощо), оскільки 
чинне кримінальне процесуальне законодавство не передбачає заочної форми повідомлення про підозру.

Утруднена процедура отримання дозволу слідчого судді на проведення огляду та обшуку в житлі чи іншому володінні особи також не тільки не сприяє реалізації організаційно-тактичних принципів раптовості та несподіваності, а й несе в собі ризик витоку інформації, зокрема з канцелярії суду в момент оформлення документації (подання, ухвали), чим можуть скористатися зацікавленні особи задля організації дій 3 перешкоджання розслідуванню.

Не сприяє забезпеченню застосування дієвих заходів подолання протидії розслідуванню відсутність у чинному Кримінальному процесуальному кодексі України окремих, самостійних статей, що регламентують процедуру реалізації програми захисту осіб, які беруть участь у кримінальному судочинстві. На нашу думку, це крок назад порівняно з КПК 1960 року, у якому в ст. 521, 52², 523 $, 52^{4}, 52^{5}$ надавався не лише перелік осіб, щодо яких здійснюються заходи безпеки, але й їх права i обов'язки, порядок забезпечення нерозголошення відомостей про цих осіб, можливість оскарження рішень про відмову в застосуванні заходів безпеки або їх скасування. Переконані, що ці прогалини в чинному законодавстві потребують свого унормування, що буде сприяти запобіганню перешкоджання розслідуванню.

Протидію розслідуванню розглядають як діяльність, здійснювану в найрізноманітніших формах, які в криміналістичній літературі прийнято поділяти на зовнішні та внутрішні, активні та пасивні, безпосередні та опосередковані. Так, Р. С. Бєлкін до внутрішньої протидії відносив діяльність осіб, причетних у будь-якій формі до розслідування (підозрюваних й обвинувачуваних, свідків й потерпілих, фахівців й експертів, випадкових осіб, які опинилися на місці події тощо), а до зовнішньої протидії - діяльність осіб, пов'язаних зі слідчим процесуальними, службовими або іншими владними відносинами або залежностями [13, с. 130].

О. В. Александренко до безпосередньої (прямої) форми протидії зараховує: давання незаконних вказівок про «згортання» розслідування; закриття окремих епізодів або всієї справи стосовно конкретних осіб і притягнення до кримінальної відповідальності інших осіб. До опосередкованої (прихованої): безпідставне вилучення кримінальної справи, матеріалів з провадження слідчого, судді; відмова в наданні необхідних сил та засобів для забезпечення належного проведення розслідування; відволікання слідчого оперативного працівника, які зайняті розслідуванням складної, багатоепізодної кримінальної справи, на роботу за малозначними справами тощо [14, с. 8].

Підсумовуючи різноманітні форми, В. М. Карагодін до дій 3 перешкоджання розслідуванню зараховує такі акти:

- що перешкоджають розкриттю злочину (виявленню події в цілому, окремих обставин, злочинного характеру події, деяких епізодів злочинної діяльності, установленню участі суб'єктів злочину та їхньої ролі); 
- що сприяють притягненню до кримінальної відповідальності невинних осіб;

- що заважають установленню характеру й розміру збитків від злочину;

- що заважають установленню обставин, що характеризують винного та впливають на ступінь і характер його відповідальності;

- які ускладнюють встановлення причин і умов, що сприяли вчиненню злочинів [15, с. 67].

На думку В. І. Кулікова, методами тиску на слідство в деяких випадках є: створення цілої системи неправдивих свідчень через підкуп; безперервні скарги в різні інстанції безпосередньо незацікавлених у справі осіб, перевірка яких відволікає слідство, даючи злочинним формуванням можливість виграти час; висунення обвинуваченими, підозрюваними та їхнім оточенням офіційних звинувачень на адресу слідчих в упередженості, вимаганні хабара, порушенні процесуальних або моральних норм, у застосуванні протизаконних методів розслідування; негативне висвітлення перебігу розслідування в засобах масової інформації через корумпованих осіб, що створює труднощі в роботі з населенням; використання будь-якого приводу (тяжка хвороба, самогубство, їх симуляція) для покладання відповідальності за це на працівників, які ведуть слідство [16, с. 144].

Л. І. Аркуша й собі до методів тиску на слідство відносить:

- створення негативної спекулятивно-ажіотажної суспільної атмосфери, що штучно підігрівається навколо розслідування. У засобах масової інформації замовляють публікації, що позитивно характеризують підозрюваних, підкреслюючи водночас недоліки слідства (вигадані або дійсні, але в перебільшеному вигляді) щодо зловживань з боку слідчого та інших учасників досудового розслідування;

- поширення явно неправдивих чуток навколо події, яка розслідується, скажімо про політичне підгрунтя справи;

- організація пікетувань, голодувань i незаконних демонстрацій, протестів представників громадських рухів і партій, що розглядають розслідування як «замах» влади на демократичні засади $[17$, с. 97, с. 98 ].

На переконання О.В.Юнацького, до найбільш поширених прийомів і методів протидії розслідуванню належать такі:

- вплив на свідків і потерпілих з метою змусити їх змінити або надати показання, що є вигідними для підозрюваного, обвинуваченого. Для цього використовують підкуп, шантаж, погрози вбивством, викрадення дітей. Тому нерідко свідки, потерпілі змушені змінювати або відмовлятися від раніше наданих ними показань, а заходи слідчого, відповідно, мають бути своєчасними та дієвими;

- організація протидії розслідуванню за участю представників органів законодавчої або виконавчої влади, суду, прокуратури, правоохоронних органів або засобів масової інформації. Така протидія має певну мету: закриття або «розвал» кримінальної справи, звільнення підозрюваного або обвинуваченого 3-під варти. До того ж не виключені заходи щодо дискредитації самого слідчого, у провадженні якого перебуває кримінальна справа, або призначення слідчого на більш відповідальну посаду з більшим 
обсягом роботи, що зумовлює потребу в передачі кримінальної справи іншому слідчому;

- використання перерви в розслідуванні 3 огляду на зупинення провадження в справі для організації активної протидії дальшому збиранню доказів. У тому разі, коли до протидії розслідуванню залучені працівники прокуратури, у справі будуть даватися численні вказівки щодо провадження окремих процесуальних та слідчих дій, іноді таких, виконання яких практично неможливе. Кримінальну справу також можуть кілька разів витребувати для перевірки та повернути на додаткове розслідування з метою перешкодити направленню іï до суду [18, с. 186-188].

3 огляду на наведене вважаємо за доцільне висловити такі міркування:

1) протидію розслідуванню варто розглядати як різновид протиправної поведінки учасників кримінального провадження або інших зацікавлених осіб (для підозрюваних, обвинувачених - це продовження реалізації їхнього злочинного наміру), що спрямована не лише на блокування провадження якої-небудь слідчої (розшукової) дії, а й на перешкоджання досягненню кінцевої мети, отриманню конкретного результату (встановленню всіх обставин вчиненого кримінального правопорушення $\bar{и}$ доведення винуватості конкретної особи тощо). «Тому найбільшу загрозу збереженню доказів, - наголошує С. Ф. Денисюк, - несе не об'єктивний перебіг часу, а свідома протидія осіб, зацікавлених у перекручуванні результатів розслідування» [19, с. 183]. 3 огляду на це вважаємо за доцільне дії підозрюваних, обвинувачених 3 перешкоджання розслідуванню (судовому розгляду) відносити до обставин, що обтяжують покарання, а для потерпілих, свідків, обізнаних та інших осіб як привід відкриття стосовно них кримінального провадження.

Водночас не є протиправними, а відтак такими, що перешкоджають розслідуванню, дії як гарантії права на захист, зокрема, право підозрюваного, обвинуваченого не говорити нічого щодо підозри проти нього, обвинувачення або в будь-який момент відмовитися відповідати на запитання (п. 4 ч. 3 ст. 42 КПК), право допитаної особи не відповідати на запитання 3 приводу тих обставин, щодо надання яких є пряма заборона в законі (таємниця сповіді, лікарська таємниця, професійна таємниця захисника, таємниця нарадчої кімнати тощо) або які можуть стати підставою для підозри, обвинувачення у вчиненні нею, близькими родичами чи членами іï сім'ї кримінального правопорушення, а також щодо службових осіб, які виконують негласні слідчі (розшукові) дії, та осіб, які конфіденційно співпрацюють 3 органами досудового розслідування (ч. 8 ст. 224 КПК), право в сторони захисту на ініціювання провадження окремих слідчих (розшукових) дій, до прикладу, клопотання про залучення експерта (ст. 243, 244 КПК) тощо. Безперечно, зазначені дії об'єктивно, певною мірою, перешкоджають оптимальній організації розслідування, утруднюючи діяльність слідчого, ставлячи його в безвихідь, змушуючи діяти в дефіциті часу, у конфліктних умовах, але вони (дії) не належать до розряду протидії розслідуванню;

2) протидія розслідуванню має носити усвідомлений характер, тобто учасник кримінального провадження або інша зацікавлена особа як суб'єкт 
протидії усвідомлює небезпеку своїх дій, передбачає можливість або неминучість настання небезпечних наслідків і бажає їхнього настання. Тому здебільшого діяльність, пов'язана з протидією, здійснюється 3 конкретним наміром - перешкоджати, не допустити, сховати, вплинути, знищити тощо;

3) криміналістичне дослідження проблем протидії розслідуванню має мати два взаємозв' язаних аспекти: аналіз форм, суб'єктів і мотивів протидії розслідуванню та створення на цій підставі дієвої системи заходів подолання.

Емпіричні дані, отримані в процесі опитування 200 слідчих, підтверджують, що найбільш розповсюдженими формами протидії розслідуванню з боку працівників правоохоронних органів, які перевищили владу або свої службові повноваження, є:

- вплив на заявника або потерпілого, їхніх рідних, членів сім'ї (шантаж, погрози, підкуп - давання їм «відкупних») для зміни змісту заяви, раніше наданих показань або до давання неправдивих показань (на цю форму вказали 70\% опитаних нами респондентів);

- схиляння або примушування свідків (передусім серед співробітників правоохоронних органів) до давання показань на користь підозрюваних - 45\%;

- знищення або приховання слідів злочину, окремих речових доказів (підроблення записів у журналах обліку затриманих; знищення записів 3 камер відеоспостереження) - 26,5\%;

- вплив на судово-медичних експертів для фальсифікації висновків щодо ступеня тяжкості тілесних ушкоджень потерпілого - 6,5\%;

- заявлення необгрунтованого алібі, зокрема через фальсифікації документів, добирання лжесвідків - 24,5\%;

- симуляція психічного розладу - 5,5\%;

- інформування підозрюваного (обвинуваченого), який перебуває під вартою, і пов'язаних з ним осіб про плани з розслідування, розголошення інформації про свідків з боку обвинувачення - 57\%;

- вплив на слідчого (обіцянка незаконної винагороди, просування по службі, нагадування про корпоративні стосунки, «честь» мундира тощо) у спосіб схиляння до прийняття законного, але більш м’якого рішення (наприклад, обрання як запобіжного заходу особистої поруки, застави чи домашнього арешту замість тримання під вартою) або ухвалення незаконного рішення (скажімо, необгрунтованого припинення або закриття кримінального провадження, відмови в прийнятті заяви чи повідомлення, відкладення на невизначений термін оголошення про підозру) - 73,5\%;

- дискредитація слідчого, який здійснює провадження (чисельні скарги на нібито порушення процесуальних та етичних норм, упередженість, вимагання хабара, негативне висвітлення перебігу розслідування в засобах масової інформації через корумпованих осіб), або призначення слідчого на більш відповідальну посаду з більшим обсягом роботи, що зумовлює потребу в передачі матеріалів провадження іншому слідчому, для закриття кримінального провадження або «розвалу» кримінальної справи, звільнення підозрюваного або обвинуваченого з-під варти тощо - 64\% ;

- відсторонення слідчого від здійснення кримінального провадження (наприклад, подача скарг на нібито неправомірні дії слідчого, вплив на нього 
через вищих за посадою співробітників органів внутрішніх справ, прокуратури тощо) - 32,5\%;

- навмисне затягування строків кримінального провадження (безпідставне вилучення матеріалів кримінального провадження для проведення чергової перевірки; відмова процесуального керівника в узгодженні рішень слідчого, передбачених у КПК, з проведення окремих слідчих (розшукових) та негласних слідчих (розшукових) дій; зволікання в наданні необхідних сил та засобів для забезпечення належного проведення розслідування (до прикладу, створення слідчо-оперативної групи або бригади слідчих); відволікання слідчого, оперативного працівника, які зайняті в здійсненні складного, багатоепізодного кримінального провадження, на виконання окремих, другорядних доручень тощо - 52,5\%.

Аналіз одержаних емпіричних спостережень надає підстави стверджувати, що особливість протидії розслідуванню з боку співробітників правоохоронних органів, які перевищили свої службові повноваження, виявляється не лише у формах їі реалізації, а й у суб'єктному складі. Поряд 3 традиційними, усталеними суб'єктами, такими, як підозрювані (обвинувачені), їхні співучасники, родичі, близькі, знайомі та захисники, активну участь у протидії розслідуванню беруть корумповані службовці органів влади, суду, прокуратури, національної поліції, пенітенціарної служби, засобів масової інформації. Саме з огляду на їхні протиправні дії реалізується переважна більшість вищезазначених форм протидії розслідуванню, саме їхні дії створюють найбільшу небезпеку та унеможливлюють запровадження дієвих засобів нейтралізації цього негативного соціального явища.

Що ж до розроблення засобів подолання протидії розслідуванню, то вважаємо за доцільне приєднатися до позиції О. В. Александренко та С. Ф. Денисюка, які зазначають, що для створення дієвої та ефективної системи заходів подолання протидії розслідуванню та розгляду справ у суді потрібно чітко виділяти такі рівні: 1) те, що може бути подолано самим конкретним слідчим, оперативним працівником через застосування оптимальних тактичних прийомів, операцій, комбінації, новітніх технічних засобів задля відшукання прихованих слідів, об'єктів, що мають значення для кримінального провадження; використання сучасних досягнень i можливостей експертних досліджень; узагальнення способів протидії окремих суб'єктів (адвокатів, різних «заступників» злочинців) для вживання відповідних заходів щодо їх подолання в процесі розслідування; ужиття заходів щодо захисту потерпілих, свідків, інших учасників кримінального провадження тощо; 2) що можливо здійснити лише Національною поліцією України або правоохоронними органами держави загалом (скоординовані дії органів досудового розслідування та оперативних підрозділів; присічення дій корумпованих співробітників правоохоронних органів або засобів масової інформації, спрямованих на протидію розслідуванню; створення та використання дієвої та ефективної системи обліків, інформаційних масивів для попередження, виявлення й подолання протидії тощо; 3) що реально може бути здійснено лише на рівні держави (створення ефективної системи захисту учасників кримінального провадження; належне законодавче й 
матеріально-технічне забезпечення правоохоронної діяльності; удосконалення системи професійного відбору на службу та навчання до відомчих навчальних закладів вищої освіти для унеможливлення потрапляння кандидатів, схильних до зради інтересів служби; унесення до навчальних планів вишів спецкурсів з проблем протидії та ії подолання тощо) [14, с. 11$13 ; 19$, с. 186-189].

До запропонованих вище заходів уважаємо за доцільне ввести необхідність проведення кримінологічної експертизи нормативно правових актів через призму чинного антикорупційного законодавства та активізації діяльності Державного бюро розслідувань за умов належного його комплектування відповідними кадрами.

Висновки. Отже, під протидією розслідуванню розуміємо будь-які дії чи бездіяльність, спрямовані на перешкоджання досягненню завдань розслідування, приховання слідів злочинів, вплив на учасників кримінального провадження, створення перешкод при відшуканні криміналістично значущої інформації, формуванні системи доказів.

3 огляду на зазначене вважаємо за доцільне залучення протидії розслідуванню як самостійного структурного елемента окремої криміналістичної методики розслідування службових злочинів, де типізовані знання про форми, методи, прийоми, суб'єктів протидії розслідуванню дають змогу надати науково-методичні рекомендації щодо нейтралізації дій, спрямованих на перешкоджання розв'язанню окремих завдань розслідування ѝ здійсненню всебічного, повного та об'єктивного кримінального провадження загалом.

\section{Використані джерела:}

1. Стулин О. Л. Тактические основы преодоления умьшшенного противодействия расследованию преступлений : автореф. дис. ... канд. юрид. наук: 12.00.09. СанктПетербург, 1998. 20 с.

2. Трухачев В. В. Правовые средства предупреждения и нейтрализации преступного противодействия на доказательственную информацию : дис. ... докт. юрид. наук: 12.00.09. Воронеж, 2001. 315 с.

3. Шехавцов Р. М. Форми та способи протидії розслідуванню злочинів і засоби їх подолання (за матеріалами кримінальних справ про вимагання), вчинені організованими групами, злочинними організаціями) : автореф. дис. ... канд. юрид. наук: 12.00.09. Київ, 2003. 20 с.

4. Щур Б. В. Тактика нейтралізації протидії розслідуванню злочинів, вчинених організованими групами : автореф. дис. ... канд. юрид. наук: 12.00.09. Харків, 2005. 20 с.

5. Цховребова И. А. Допустимо ли относить адвоката-защитника к субъектам противодействия расследованию? Расследование и противодействие ему В состязательном уголовном судопроизводстве: процессуальные и криминалистические Bопросы: сб. науч. тр. Москва, 2007. С. 409-412.

6. Бажанов С. В. Адвокат-защитник как субъект противодействия предварительному расследованию. Расследование $u$ противодействие ему $b$ состязательном уголовном судопроизводстве: процессуальные и криминалистические Bопросы: сб. науч. тр. Москва, 2007. С. 54-58. 
7. Бабаева Э. У. Некоторые теоретические и практические аспекты учения о преодолении противодействия уголовному преследованию. Москва: Русинжкомлект, 2004. 132 c.

8. Гармаев Ю. П. Незаконная деятельность адвокатов в уголовном судопроизводстве. Москва: Экзамен, 2005. 390 с.

9. Гармаев Ю. П. Влияние адвоката-защитника на показания подозреваемого (обвиняемого): каковы его пределы? Сибирский юридический Вестник. 2003. № 2. С. 18-23.

10. Баев М. О. Теория профессиональной защиты: тактико-этические проблемы. Москва: Юрлитинформ, 2006. 336 с.

11. Баев М. О. Противодействие как реализация принципа состязательности в уголовно-процессуальном исследовании преступлений. Воронежские криминалистические чтения. Воронеж: Изд-во Воронеж. гос. ун-та, 2005. Вып. 6. С. 5-9.

12. Гордейчик С. Злоупотребление правом на защиту. Законность. 2006. № 12. С. 6-8.

13. Криминалистическое обеспечение деятельности криминальной милиции и органов предварительного расследования : учебник / под ред. Т. В. Аверьяновой, Р. С. Белкина. Москва: Новый Юрист, 1997. 400 с.

14. Александренко О.В. Криміналістичні проблеми подолання протидії розслідуванню : автореф. дис. ... канд. юрид. наук : 12.00.09. Київ, 2004. 20 с.

15. Карагодин В. Н. Преодоление противодействия предварительному расследованию. Свердловск: Изд-во Урал. гос. ун-та, 1992. 175 с.

16. Куликов В.И. Основы криминалистической теории организованной преступной деятельности. Ульяновск: Филиал МГУ, 1994. 256 с.

17. Аркуша Л. И. Некоторые способы преодоления противодействия следствию при расследовании преступлений, совершенных организованными преступными формированиями с использованием коррумпированных связей. Актуальні проблеми держави та права: зб. наук. пр. Одеса: Астропринт, 1998. Вип. 5. C. 96-99.

18. Юнацький О.В. Особливості діяльності слідчого в умовах протидії розслідуванню злочинів. Вісник Запорізького юридичного інституту. Запоріжжя: ЗЮІ, 2009. Вип. № 3. С. 186-188.

19. Денисюк С. Ф. Подолання протидії розслідуванню: організаційні й тактичні заходи. Вісник Харківського національного університету внутрішніх справ: зб. наук. пр. Харків: ХНУВС, 2011. Вип. № 2 (53). С. 183-189.

Стаття надіӥшла до редколегії 16.01.2019

Федоренко М. С., аспирант кафедры уголовного права и процесса Львовского торгово-экономического университета (г. Львов, Украина)

Противодействие со стороны заинтересованных лиц и средства его преодоления при расследовании превышения власти или служебных полномочий сотрудниками правоохранительных органов

В статье рассмотрены концептуальные подходы к пониманию противодействия расследованию со стороны заинтересованных лиц, выделены формы, виды, приемы, круг субъектов, пути и средства эффективного преодоления этих противоправных действий. Предложено под противодействием расследованию понимать любые действия или бездействие, направленные на препятствие достижению задач расследования, сокрытие следов преступлений, воздействие на участников уголовного производства, создание преград при отыскании криминалистически значимой информации, 
формировании системы доказательств. Опираясь на результаты эмпирического наблюдения, выделены наиболее распространенные формы противодействия расследованию со стороны сотрудников правоохранительных органов, превысивших власть или служебное положение. Подчеркнуто, что наряду с традиционными, устоявшимися субъектами, такими, как подозреваемые (обвиняемые), их соучастники, родные, близкие, знакомые, защитники, активное участие в противодействии расследованию принимают коррумпированные служащие органов власти, суда, прокуратуры, национальной полиции, пенитенциарной службы, средств массовой информации. Обращено внимание на то, что эффективная система преодоления противодействий расследованию включает несколько уровней, где особое значение приобретают рекомендации о необходимости проведения криминологической экспертизы нормативно правовых актов через призму действующего антикоррупционного законодательства и активизации деятельности государственного бюро расследования при условии надлежащего его комплектования соответствующими кадрами.

Ключевые слова: досудебное расследование превышения власти или служебных полномочий сотрудниками правоохранительных органов, противодействие со стороны заинтересованных лиц, формы противодействия расследованию, субъекты противодействия расследованию, средства преодоления противодействия расследованию.

\section{Fedorenko M. Counteraction from the Side of Interested Persons and Methods of its Overcoming while Investigating Exceeding of Power or Official Authority by Law Enforcement Officers}

The article deals with conceptual approaches to the understanding of the counteraction to the investigation by interested persons, the forms, types, methods, circle of subjects, ways and means of an effective overcoming of these unlawful actions are distinguished. It has been suggested to divide scientists-criminologists into supporters of a narrow and broad understanding of this criminalistics category according to their views on the notion of counteraction to the investigation. The author's definition of the concept of counteraction to investigation has been provided, which should be understood as any actions or inaction aimed at interfering with the accomplishment of the objectives of the investigation, the concealment of traces of crimes, the impact on the participants in criminal proceedings, the creation of obstacles in seeking criminalistically meaningful information, the formation of a system of evidence. Based on the results of empirical observation, the most common forms of counteracting the investigation by law enforcement officers have been identified, namely: the impact on the applicant or the victim, their relatives, family members in order to change the content of the application, previously provided testimony; inclining or forcing witnesses to testify in favor of suspects; destruction or concealment of traces of a crime, certain material evidence; influence on forensic experts in order to falsify conclusions about the degree of gravity of bodily injuries of the victim; statement of unjustified alibi, selection of false witnesses; simulation of a mental disorder; disclosure of witness information; influence on the investigator, his discredit or removal from criminal proceedings; deliberately delaying the criminal proceedings. It has been emphasized that corrupt officials of the authorities, of the court, of the prosecutor's office, of the national police, of the penitentiary service and of the media take an active part in counteracting the investigation, along with traditional, well-established subjects such as suspects (accused), their accomplices, relatives, friends, acquaintances and defenders. Attention is drawn to the fact that an effective system of measures to 
overcome the counteraction to investigations involves several levels, where the recommendations concerning the necessity of criminological examination of normative acts in terms of the current anti-corruption legislation and the activation of the activities of the State Bureau of Investigation, provided that they are adequately staffed by the relevant personnel, are of a particular importance.

Key words: pre-trial investigation of excess of power or official authority by law enforcement officials, counteraction from interested persons, forms of counteraction to the investigation, subjects of counteraction to investigation, means of overcoming the counteraction to the investigation.

\section{ОРГАНІЗАЦІЙНО-ПРАВОВІ ОСНОВИ ЗАХИСТУ ВЛАСНОСТІ ЗАСОБАМИ ОХОРОННОЇ ТЕХНІКИ В УКРАЇНІ}

У статті розглянуто охоронну техніку як складову спеціальної техніки. Як наукова категорія охоронна техніка являє собою сукупність наукових положень $\mathrm{i}$ рекомендацій щодо застосування технічних, програмно-технічних, програмних засобів, речовин, інформаційних систем, наукових і спеціальних методів їх використання під час виконання завдань суб'єктами охоронної діяльності. Визначено систему та проблеми охоронної техніки.

Система охоронної техніки складається 3 таких елементів: загальних положень, напряму застосування та функціонального призначення засобів охоронної техніки. Виділено правові засади використання охоронної техніки та організаційні структури їі застосування для охорони об'єктів. Показано, що нормативно-правові акти, які становлять правову основу захисту майна та застосування технічних засобів охорони, належать до різних галузей права. Визначено категорію «організація технічної охорони об'єктів», ії класифікацію та перспективи розвитку.

Ключові слова: охоронна техніка, охоронна діяльність, категорія, класифікація, організація, перспектива.

Постановка проблеми. В Україні охорону об'єктів державної та інших форм власності здійснюють учасники ринку охоронних послуг, на якому діють поліція охорони та приватні охоронні структури. Забезпечення безпеки власності в сучасних умовах є особливо актуальним через зростання кваліфікованих злочинів, економічною нестабільністю, комп'ютерними злочинами, промисловим шпигунством.

Засоби захисту людини та ії майна розроблялися протягом тривалого періоду - від найпростіших засобів фізичного захисту житла людини до сучасних систем безпеки. Найбільшого поширення набули системи охоронно-пожежної сигналізації, застосування яких досить ефективно вирішує проблеми забезпечення безпеки за допомогою технічних засобів охорони.

(C) Хараберюш I. Ф., 2019 